\title{
The Need For Utilising the Potential of the Hungarian Development Agencies
}

\section{Summary}

Even though the regional development agencies have been an essential tool in the territorial development policy in the past seven decades, the changing paradigm of the European regional policy is questioning the need of traditional tools. Countries like Hungary have already decided to run the 2014-2020 EU budgetary period in a new institutionalized setup. This study attempts to highlight the historical adaptation of development institutions and points out that in a knowledgebased economy only those governments are able to boost competitiveness and the absorption rate which have institutions enabling adaptability and knowledge transfer.

Journal of Economic Literature (JEL) codes: O18, P25, R11

Keywords: development agencies, territorial development, European regional policy, competitiveness

\section{INTRODUCTION}

After WW2, the democratic countries of Europe became part of an economic transformation, mainly characterized by market orientation and the liberalization of inter- national trade. Globalisation very soon highlighted the importance of the territorial systems in production. It became obvious that some territories had the potential to exploit on a higher extent the advantages of the forming structures. As the central and territorial administrations started to focus on support to entrepreneurs, the link between public and the private spheres grew tighter. As the new area of expertise was evolving, research soon started in relation to the institutions that were supposed to implement the territorial policies. The governments of the developed countries, the European Communities, also encouraged the capacity building between the member states. Territorial development agencies (TDAs) were brought into the focus of the new studies on the institutional side of territorial development. Since the 1960's these organisations have become a fundamental part of the European territorial development systems. As a consequence, TDAs' portfolios and their instruments were constantly broadened throughout the decades and they served as the best institutional practice for candidate countries. TDAs, especially in relation to the disbursement of EU funds, had also become part of the enlargement negotiations. Of all

Balázs Simó, senior advisor, Ministry of National Development, Hungarian Development Center (simo.balazs.mate@gmail.com). 


\section{Tudományos múhely}

the enlargement rounds, negotiations with the post-socialist countries were the most challenging for all sides. At the beginning of the 1990's, these states had to set up a legal framework and the operating structures for liberal democracies and for a free market on the ruins of socialist regimes. The change of regime also widened the gap between the territories. Therefore, and also to fulfil the EU requirements, these candidate countries started to be increasingly committed to the territorial development approach. But the establishment of Hungarian RDAs and the legal background of their operation was hindered. As Pálné Kovács (2003) stressed already before the $\mathrm{EU}$ accession, the inadvertent law and the unstable financial background of the institutions were barriers to the capacity building of the Hungarian Regional Development Agencies. In spite of all the hardships regarding their establishment, the Hungarian Regional Development Agencies were active contributors to the territorial development already in the EU budgetary period of 20042006. Besides the promising existence of the agencies, by the end of the period Sárközy (2006) warned that if the overall reform of the public sector did not take place, Hungary would lose its chances to catch up with the more developed countries. The reform also supposed to include the settlement of an adequately regulated and financed institutional system for territorial development. Finally in 2011 the cabinet decided to modify Act XXI on Regional Development and Regional planning. RDAs, which had operated as intermediate bodies (IBs) in the Regional Operational Programmes throughout the EU financing period 20072013, were abolished. In the meantime, for the next programming period (2014-2020) the Hungarian State Treasury has the same tasks regarding the EU funds management. The modification also affected the territorial development policy: the legitimate counties became solely responsible instead of the planning regions. Their municipalities have already begun to set up their own agencies, mainly by utilizing some of the remaining resources of RDAs that they used to own. Cities having a county status also started to rapidly build such capacities as well, so the question arises: development agencies still have the potential to serve as the operative backbone of territorial development to enhance competitiveness in the future? To answer these questions, the territorial agencies' history and adaptability to the knowledge-based economy have to be studied. Highlighting the constant evolution of TDAs might bring us closer to the streamlining proposals regarding the operative part of the institutional system of Hungarian territorial development.

\section{TDAs' ADAPTATION AND EVOLUTION}

As national governments tried to counterbalance the widening of territorial gaps during the 1960's in democratic countries, territorial governance had evolved as a new discipline. In the traditional approach, public institutions' decision-making simply could not keep pace with the needs. As a result, the resolutions were made late and the policies were unable to reach their targets. These failures had their negative impacts on all those stakeholders whose competitiveness and production processes largely depended on the territorial infrastructure and the overall development stage of the local logistics. In order to meet the challenges, new governing methods and techniques, ways of exercising power had to be put in practice. Public institutions were expected to serve as an interface besides the fulfilment of their regulatory roles. The above-mentioned evolution procedure took decades. Tables 1 and 2 demonstrate the phases of development, and the organisational and institutional models.

As an outcome, New Public Management (NPM) and then the New Public Governance (NPG) gradually gained influence over traditional public administration in the 1990's (Osborne, 2010). The tradi- 
Table 1: Three phases of development and the organisational models

\begin{tabular}{l|l|l|l}
\hline & \multicolumn{1}{|c|}{$\mathbf{1 9 5 0}$ 's } & \multicolumn{1}{c}{$\mathbf{1 9 7 0}$ 's } & \multicolumn{1}{c}{ 1990's } \\
\hline $\begin{array}{l}\text { Organisational } \\
\text { paradigms }\end{array}$ & Fordism & $\begin{array}{l}\text { individual entrepreneurship } \\
\text { customer orientation }\end{array}$ & $\begin{array}{l}\text { integrated systems } \\
\text { just in time }\end{array}$ \\
\hline Production units & large firms & small firms & networks \\
\hline $\begin{array}{l}\text { Organisational } \\
\text { objectives }\end{array}$ & Growth & value of differences & $\begin{array}{l}\text { put order in } \\
\text { heterogeneity }\end{array}$ \\
\hline Performance criteria & $\begin{array}{l}\text { production } \\
\text { costs }\end{array}$ & quality of products & time of processes \\
\hline $\begin{array}{l}\text { Factors of } \\
\text { competitiveness }\end{array}$ & $\begin{array}{l}\text { economies } \\
\text { of scale }\end{array}$ & $\begin{array}{l}\text { flexibility and in house } \\
\text { product and process } \\
\text { innovation }\end{array}$ & $\begin{array}{l}\text { synergy, networking } \\
\text { organisational } \\
\text { innovation }\end{array}$ \\
\hline
\end{tabular}

Source: Cappellin, 1996:9

Table 2: Three phases in development and institutional models

\begin{tabular}{|c|c|c|c|}
\hline & 1950's & 1970's & 1990's \\
\hline Institutional models & Centralism & $\begin{array}{l}\text { territorial autonomy } \\
\text { self-centred federalism }\end{array}$ & $\begin{array}{l}\text { networks of contracts } \\
\text { cooperative federalism }\end{array}$ \\
\hline $\begin{array}{l}\text { Principles of interde- } \\
\text { pendence }\end{array}$ & $\begin{array}{l}\text { hierarchical } \\
\text { coordina- } \\
\text { tion }\end{array}$ & principal of subsidiary & $\begin{array}{l}\text { principle of coopera- } \\
\text { tion }\end{array}$ \\
\hline Role of public actors & $\begin{array}{l}\text { public ow- } \\
\text { nership } \\
\text { interventi- } \\
\text { onism }\end{array}$ & $\begin{array}{l}\text { legislative regulation } \\
\text { jurisdictional activity } \\
\text { promote the actors }\end{array}$ & $\begin{array}{l}\text { integration } \\
\text { collective entrepre- } \\
\text { neurship }\end{array}$ \\
\hline
\end{tabular}

Source: Cappellin, 1996:9

tional approach was replaced by the territorial one, new development policies emerged to meet the challenges of the backward territories. Table 3 indicates the distinction between the policies of the traditional and the territorial one followed in the $90 \mathrm{~s}$.

The very first TDAs were established in the 1950's in the developed countries. Halkier and Danson (Halkier-Danson, 1995:41) highlighted the most important advantages of these institutions from the very beginning. They could be characterized with flexibly approach to the local needs and challenges. In the meantime, they had the possibility to strive for the achievement of the public goals in a manner that was previously only known in the private sector. As they were locally based, the agencies proved to be much more capable of dealing with the specific challenges of the territorial units. The bottom-up approach also required staff that did not only have a business view but was also capable of working together with the stakeholders of the different branches of the economy (Halkier-Danson, 1995:41). From the start TDAs could exploit the endogenous potential of the territories. Instead of the equalization mechanisms, they rather focused on the investment promotion. In the case of the backward regions the shortage of capital, resources and the market failures were named as the most crucial factors. So the economic poli- 
Table 3: Traditional and territorial policies of backward regions

\begin{tabular}{l|l|l}
\hline & \multicolumn{1}{|c|}{ Traditional } & \multicolumn{1}{c}{ Territorial } \\
\hline \multirow{4}{*}{ Challenges } & lack of capital & lack of entrepreneur \\
\cline { 2 - 3 } & lack of qualified labour & inadequate innovation \\
\cline { 2 - 3 } & $\begin{array}{l}\text { exploiting the potential of economies } \\
\text { of scale }\end{array}$ & lack of internationalization \\
\cline { 2 - 3 } Strategies & $\begin{array}{l}\text { territorial policies as a protection } \\
\text { against the international competition }\end{array}$ & lack of specific know-how \\
\cline { 2 - 3 } & $\begin{array}{l}\text { equalizing state interventions for back- } \\
\text { ward territories }\end{array}$ & $\begin{array}{l}\text { efficiency based on territorial poli- } \\
\text { cies }\end{array}$ \\
\hline \multirow{3}{*}{ Goals } & guarantee of price competition & lowering transaction costs \\
\cline { 2 - 3 } & lowering production costs & lowering adaptation costs \\
\hline \multirow{4}{*}{ Tools } & subsidies for companies & $\begin{array}{l}\text { services supporting production } \\
\text { processes }\end{array}$ \\
\cline { 2 - 3 } & direct transfer to households & territorial policy \\
\cline { 2 - 3 } & & Inter-territorial cooperation \\
\hline \multirow{3}{*}{ Effects } & $\begin{array}{l}\text { no room for self-sustaining develop- } \\
\text { ment }\end{array}$ & self-sustaining development \\
\cline { 2 - 3 } & growing dependence & international competition \\
\hline
\end{tabular}

Source: Cappellin, 1996

cies also tried to reflect and mitigate these type of challenges. Interventions were made to decrease the cost of production, which was looked upon as a barrier to the flow of the capital into the region. In most cases industrial sites were established by direct state subsidies. The enhancement of economic activity was measured mainly by aggregated indicators. But the growing inefficiency of the traditional development policies gave room to new regional development theories. Soon low unemployment rate became the final goal to achieve by increase in productivity, liquidity and the volume of exports. New firms had to be established and the competitiveness and export activity of the existing ones had to be improved. So TDAs had to create their own sophisticated tools to fulfil their role and become capable of carrying out discretional proactive activities. Due to the abovementioned operational freedom, agencies first became supplementary and then inevi- table parts of governments' development activities (Danson et al., 1998:17-21). Besides centrally delegated tasks, TDAs started to carry out new activities: cross-border activities, among other soft measures (e.g. consultancy) also enjoyed bigger emphasis. In the meantime they became increasingly eager to take territorial coordinative and facilitator roles. In addition to the institutions and their methods, the available funds also evolved. Instead of one-sided direct granttype tools, new funds emerged in the areas of $\mathrm{R} \& \mathrm{D}$, innovation, internationalization, infrastructure and SME development. Table 4 demonstrates the fundamental policy differences between the central bodies and TDAs, while Table 5 illustrates agency tools.

Since the 1990's it has been no longer sufficient to take part in planning, enhance networking and increase the overall volume of the incoming FDI to the territory. The follow-up activities have become especially important for backward regions, as the first 


\section{Tudományos múhely}

Table 4: Territorial policy approach to the central bodies and TDAs'

\begin{tabular}{l|l|l}
\hline \multirow{2}{*}{ Organisation } & \multicolumn{1}{|c|}{ Central } & \multicolumn{1}{c}{ TDA } \\
\cline { 2 - 3 } & central & territorial \\
\cline { 2 - 3 } & central government organ & quasi-independent organisation \\
\cline { 2 - 3 } & bureaucratic & market-based \\
\cline { 2 - 3 } Openeral qualification & specific knowledge \\
\hline Economic goal & restricted & arm's length independence \\
\cline { 2 - 3 } & Inter-territorial inequality & Inter-territorial competitiveness \\
\cline { 2 - 3 } & growth in the national economy & growth in territorial economy \\
\cline { 2 - 3 } Operating method & non-selective & endogenous/imported growth \\
\cline { 2 - 3 } & automatic/discretional & selective \\
\cline { 2 - 3 } & reactive & directional \\
\hline \multirow{3}{*}{ Policy tools } & bureaucratic regulation & financial incentives \\
\cline { 2 - 3 } & financial incentives & consultancy \\
\cline { 2 - 3 } & consultancy & public actions \\
\cline { 2 - 3 } & public actions & \\
\hline
\end{tabular}

Source: Danson et al., 1998

Table 5: Tools used by TDAs

\begin{tabular}{l|l|l|}
\hline Categories & \multicolumn{2}{|c|}{ Tools } \\
\hline \multirow{4}{*}{ Policy tools } & \multicolumn{1}{|c|}{ Traditional } & \multicolumn{1}{|c|}{ Territorial } \\
\hline \multirow{4}{*}{ Consultancy } & consultancy & \\
\cline { 2 - 3 } & fund disbursement & \\
\cline { 2 - 3 } & infrastructural development & \\
\cline { 2 - 3 } & & production \\
\cline { 2 - 3 } & grants & market environment \\
\cline { 2 - 3 } & & general business \\
\cline { 2 - 3 } & internationalization & \\
\hline \multirow{4}{*}{ Financing } & & financial tools \\
\cline { 2 - 3 } & own call for proposals & \\
\cline { 2 - 3 } & other & training \\
\hline & & establishment of industrial parks \\
\hline & & \\
\cline { 2 - 3 } & $\begin{array}{l}\text { traditional industrial } \\
\text { development }\end{array}$ & \\
\hline
\end{tabular}

Source: Halkier-Danson, 1996:13-16 
investment cannot guarantee repeated FDI transfers. Such risks were especially relevant in relation to innovative companies, which considered the networking capacity of local suppliers, public organisations and labour much more important than a one-time state subsidy. Actions such as improving the infrastructure of vocational training became increasingly important. In many places the agencies established associations which gave the opportunity to the local suppliers to take the next steps with large firms in the improvement of logistics solutions or quality management (Cooke, 1992:375-377). As a consequence of these trends, TDAs started to integrate into the local systems as new coordinators. The institutions enhanced the learning process generated by the simultaneous cooperation and competition of companies. So the general added value of the agencies could be characterized by more of a broker nature. Certainly, this meant much more than advocating "buy local". The enhancement and encouragement of spreading the new technologies had become a typical and new service of TDAs. The most promising companies undertook to carry out technological audits, which pointed out the strengths and weaknesses (MilesTully, 2007:855-866). The same goals were behind the establishments of the different technological clubs, which were supposed to facilitate the integration of technological inventions. The adaptation processes were also assisted by the different consortiums established in the field of training and education for SMEs. Thus over the decades the focus slowly shifted from direct investments to the creation of the required framework for the improvement of local marketing, research, operative and management skills (Macleod-Jones, 1999:575-605). Besides the above-mentioned activities, agencies also undertook the management of the grant distribution. In the oldest EU member states they were trusted to manage regional operational programmes co-financed by the European Union.

By the 21st century the accumulation of knowledge in an organisation and its flow inside or outside territorial units had dramatically changed. As a result the access for information and knowledge has become the driving factor of competitiveness. This trend constantly overrules the previous theories on the utilization of the endogenous potential of the different territories (Crevoisier-Jeannerat, 2009:1223-1232). Table 6 illustrates the paradigm change in the European regional policy.

The new challenges posed by the local and global environment questioned the very concepts of territorial development and TDAs (Cooke-Laurentis, 2010:1-26). In the near future geographical units will be able to improve their competitiveness if they are able not only to mobilize, but also to combine and develop the knowledge obtained and internalized. Table 7 shows the conversion to a knowledge-based paradigm.

Table 6: Changing paradigm in the European regional policy

\begin{tabular}{l|l|l}
\hline Dimension & $\begin{array}{l}\text { Industrial-economic } \\
\text { paradigm }\end{array}$ & $\begin{array}{l}\text { Knowledge-based economic } \\
\text { paradigm }\end{array}$ \\
\hline Territorial governance & $\begin{array}{l}\text { territory appointed for } \\
\text { investment }\end{array}$ & multi-layer, bottom-up approach \\
\hline Strategy & $\begin{array}{l}\text { growth generated by invest- } \\
\text { ment into private companies }\end{array}$ & $\begin{array}{l}\text { growth by new economic activities } \\
\text { thank to the increased knowledge } \\
\text { and networking schemes }\end{array}$ \\
\hline Tools & financial & information, organisations \\
\hline
\end{tabular}

Source: Halkier et al., 2012:25 
Table 7: Conversion to the knowledge-based paradigm

\begin{tabular}{l|l|l|}
\hline Unit of change & '90TIES & $\begin{array}{l}\text { New paradigm: territorial knowledge } \\
\text { dynamics }\end{array}$ \\
\hline $\begin{array}{l}\text { Mobilisation of new } \\
\text { knowledge }\end{array}$ & $\begin{array}{l}\text { Pointwise (technological } \\
\text { trajectory) }\end{array}$ & Knowledge dynamics \\
\hline $\begin{array}{l}\text { Articulation of know- } \\
\text { ledge }\end{array}$ & Accumulation & Combination \\
\hline Territorial focus & $\begin{array}{l}\text { Territorial division of } \\
\text { activities and labour }\end{array}$ & Multi-locational knowledge networks \\
\hline Territorial governance & $\begin{array}{l}\text { Territorial coherence for } \\
\text { creating and using the } \\
\text { knowledge (clusters) }\end{array}$ & $\begin{array}{l}\text { Capability of taking part in the } \\
\text { mobilisation of the multi-locational } \\
\text { dynamics of knowledge transfer by } \\
\text { acquiring the adequate capacities }\end{array}$ \\
\hline
\end{tabular}

Source: Halkier et al., 2012:206-211

So the current challenge to establish and maintain institutions which possess the tools. TDAs seem a good basis for acquiring new sets of tools because they already have a kind of coordinating capability that enables them to deal with complex problems. As Strambach stresses (Strambach, 2008:152-174), constantly changing knowledge is the source of innovation. He points out their direct interrelationship and stresses the importance of taking it into consideration in territorial policy and in the development of the institutional system. The combinative nature of knowledge and innovation requires the presence of institutions which can guarantee cross-sectoral connectivity. Governments and the agencies have to play a key role in the establishment and maintenance of such links. Halkier also highlights the trend that agency portfolios earmarked for grant or fund management are shrinking in comparison to the delivery of their institutional and informational service resources. These trends evidence the future need of sufficiently financed and politically sponsored territorial development agencies. The new services are provided by easily adapting agencies, constantly upgrading their HR and techni- cal resources to be able to maintain their territorial, national and international channels. The new generation of TDAs in the developed countries are already evolving.

\section{Summary}

Countries like Hungary have recently reacted to the new challenges with the restructuring of the development institutional system. Besides the abolishment of RDAs, the Managing Authority of the Territorial Operational Programme, which are the most important units of the EU fund management system, were integrated into the line ministry (Ministry of National Economy). The intermediary body role of RDAs are being fulfilled now by the Hungarian State Treasury and the tasks of territorial development have been delegated to the counties. Their municipalities have already begun to set up their own agencies, mainly by utilizing some of the remaining resources of RDAs that they used to own. Cities having a county status started to rapidly build such capacities as well. Coordination between the different actors (ministries, counties, cities) and their institutions will be crucially important since new set up of 
funding schemes are on the way as the start of the new budgetary period is approaching (after 2020). In the next EU financing period the fine tuning of the Cohesion Policy may be expected, and the overall budget may be cut to the tune of 20 per cent. The common budget is expected to shrink partly due to the Brexit and partly because the EU will have to spend more on issues like migration and the common security and defence policy (European Commission, 2017). Funds may be cut by as much as EUR 10 billion. As the Common Agricultural Policy and the Cohesion Policy are the areas easiest to withdraw funds from, EUR 10 billion may be quite a substantial loss in comparison to the EUR 350 billion overall Cohesion Policy budget. So far the member states have shown little inclination to raise their contributions to the budget for the next period. But besides the change in the amount of the available funds, the rules of their use and their qualitative measures are just as important issues, as part of the funds are managed through national systems and management is delegated to the Managing Authorities and Intermediate Bodies. The rest of the budget, called direct funds, is managed by the Services of the European Commission, and the applicants submit their proposals directly to its units. In the previous case there are the national operational programmes (like the Territorial Operational Programme). Their budgets are decided on an EU level as part of national envelopes. In the case of direct funds, budgets are not broken down into national sub-budgets. The amount of funds allocated to each applicant is revealed in the periods of calls for proposals. The Commission and the more developed member states intend to raise the ratio of direct funding in the upcoming period. This scenario will fit into the current trend because the proportion of direct funds in the 2000-2006 period was only 6.8 per cent, while in the current one (2014-2020) it is already 13.1 per cent. The third crucial aspect is the quality issues of the funds. So far the biggest part of the Cohesion Funds were used in a non-refundable form. From budgetary period to budgetary period the refundable ones gained territory and this trend can be expected in the next period as well. These types of tools are mainly credits, guarantees and venture capital. So not only the expected amount of the EU funds, but the growing proportion of the refundable funds will also reduce the room for manoeuvre for the future Hungarian government as well. Because it cannot be expected that the state budget will be able to counter balance the loss of the EU's national envelope and neither that the Hungarian applicants will have a higher success rate in comparison with the ones applying from the old member states for the direct funds. Also the usage of the refundable funds require such projects and investments which are highly sustainable from the business and finance point of view. These developments will need to bring such a real added value which assume a kind of territorial development system that is compatible with both central and local level. So it is in Hungary's highest interest to run a territorial development system where central and local actors can design and implement integrated development strategies, built on the social, environmental and economic strength or "assets" rather than compensating for specific territorial problems. These approaches will have an added value to the national and territorial programmes. Compared to other classical local approaches, the stakeholders who were passive "beneficiaries" of a policy become active partners and drivers of its development. For these types of new actions cooperation between the Hungarian central government, the counties and the big cities are more important than before. Trimming interoperability via such operative organs as the State Treasury and agencies of the counties and cities are essential to be more competitive by mobilizing the resources and competencies. 


\section{Tudományos múhely}

\section{REFERENCES}

Cappellin, Riccardo (1996): Federalism and the Network Paradigm: Guidelines for a New Approach in National Regional Policy. 36th European Congress, 26-30 August, European Regional Science Association, Zürich.

Cooke, Philip (1992): Regional Innovation Systems: Competitive Regulation in the New Europe. Geoforum, Vol. 23, No. 3, 365-382, https://doi. org/10.1016/0016-7185(92)90048-9.

Cooke, Philip - De Laurentis, Clara (2010): Trends and Drivers of Knowledge Economy. In: Cooke, Philip et al. (ed.): Platforms of Innovation. Dynamics of New Industrial Knowledge Flows. Edward Elgar, London.

Crevoisier, Olivier - Jeannerat, Hugues (2009): Territorial Knowledge Dynamics: From the Proximity Paradigm to Multi-Location Milieus. European Planning Studies, Vol. 17, No. 8, 1223-1241, https://doi.org/10.1080/09654310902978231.

Danson, Mike - Halkier, Henrik - Damborg, Charlotte (1998): Regional Development Agencies in Europe. An Introduction and Framework for Analysis. In: Halkier, Henrik et al. (eds.): Regional Development Agencies in Europe. Jessica Kingsley Publisher, London.

European Commission (2017): An EU budget fit for tomorrow: Commission opens debate on future of EU finances. European Commission, Brussels, http://europa.eu/rapid/press-release_IP-171795_en.htm.

Halkier, Henrik - Danson, Mike (1995): Regional Development Agencies in Europe: A Preliminary Framework for Analysis. A Regional
Futures: Past and Present, East and West. Göteborg, 6-9. May. In: Bellini, Nicola et al. (eds.): Regional Development Agencies: the Next Generation? Routledge, New York, https://doi. org/10.4324/9780203107027.

Halkier, Henrik - Danson, Mike - Bellini, Nicola (2012): Regional Development Agencies: Towards a New Generation? In: Bellini, Nicola et al. (eds): Regional Development Agencies: The Next Generation? Routledge, Abingdon.

MacLeod, Gordon - Jones, Martin (1999): Reregulating a Regional Rustbelt: Institutional Fixes, Entepreneurial Discourse, and 'Politics of Representation'. Environment and Planning D, Vol. 17, No. 5, https://doi.org/10.1068/d170575.

Miles, Nicholas - Tully, Janet M. (2007): RDA policy to tackle economic exclusion? The role of social capital in distressed communities. Regional Studies, Vol. 41, No. 6, 855-866, https://doi.org/10.1080/ 00343400601120312.

Osborne, Stephen (ed.) (2010): The New Public Governance? Emerging Perspectives on the Theory and Practice of Public Governance. Routledge, London - New York, https://doi. org/10.4324/9780203861684.

Pálné Kovács Ilona (2003): A területfejlesztés irányítása. Pécsi Tudományegyetem, Pécs.

Sárközy Tamás (2006): A kormányzás modernizálásáról. Mozgó Világ, 32. évf., 8. sz.

Strambach, Simone (2008): Knowledge-Intensive Business Service (KIBS) As Drivers of Multilevel Knowledge Dynamics. International Journal Services Technology and Management, Vol. 10, No. 2-4, https://doi.org/10.1504/IJSTM.2008.022117. 